\title{
Transducer Function In Vending Machine Simulation Design
}

\section{Tuti Andriani, Pristiwanto}

Stmik Budi Darma, Indonesia

Email : tutiandriani9530@gmail.com ${ }^{1}, 4$ t0.82@gmail.com²

Received : 25 April 2021

Revised : 25 Mei 2021

Accepted : 29 Juny 2021

(C) 2021 The Author: Published by. Cattleya Darmaya Fortuna

\begin{abstract}
A vending machine is a substitute for a cashier or admin in the form of a machine so that buyers simply enter coins and the machine will issue them according to the request. Moore machine and mealy machines as a process for processing buyer orders which are translated into machine orders. Based on the test results of coins entered 1000 and 500, the drink can be chosen according to the price of the drink. The vending machine simulation that is made can accept 500 and 1000 coins as input and produces output in the form of a description of the selected drink and the remaining coins that have been entered
\end{abstract}

Keywords: Tranducer, Simulation, Vending Machine.

\section{INTRODUCTION}

Simulation is used to study the system numerically, where data collection is carried out to perform statistical estimates to obtain the original characteristics of the system that is right for use, especially if it is necessary to conduct experiments in order to find the best comments from the system components [1]. This is because it is very expensive and takes a long time if the experiment is tried in real life. Simulation studies, in a short time, the right decision can be made and the cost is not too high because everything is done on a computer. The data processor or troubleshooter is computer software. These basic operations are compiled by programs or software. The level of processing carried out by software is also machine-like, starting to change into human-like. Computers have been used to control production machines with high precision (eg CNC, a versatile machine in the metal industry) [2]. Vending Machine modeling method with Finite State Automata to explain the logic of accepting input in the form of coins on the machine until you get a drink according to your choice [3]. A Vending machine is a food or beverage sales machine that works on a standalone basis [4].

There are several examples of finite state machines with output that can be used in research, such as vending machines, ATM machines, and others. The Inite State Machine (FSM) is a control system design methodology that describes the behavior of a [5]. The Finite State Machine is supported by the Collision Detection Algorithm as a trigger [6]. The finite state machine method serves to determine the user flow in answering a question that appears on the machine [7]. One of the AI methods is FSM (Finite State Machine), which has a system working principle using the following three things: state, event and action [8]. The Finite State Machine can be used to determine enemy movements and actions without involving the user [9]. 
There are several aspects of a vending machine that must be studied, such as how the process of running a vending machine works [10]. The purpose of this research is to find out how the quality of Vending Machine services is [11]. Vending machines generally have the principle that when a certain amount of money is entered into this machine, consumers can choose the desired product by simply pressing the button that represents the desired product [12]. Vending machines are one solution to increasing sales of snacks, because buyers can pay for and choose the snacks they want to buy independently without the help of others [13]. Therefore, it must first define from the beginning, such as input data, process data, and output data. In the input data, it must also be explained what the input is, then determine the output data or objects to be used.

\section{METHODS}

\section{Finite State Machine}

A Finite State Machine is also included in the theory of language automata that can accept input such as FA. The Finite State Machine (FSM) approach describes the behavior of a system in a state or state [14]. This finite state machine can also receive input and can issue output so that in a finite state machine there are two types of finite state machines, namely:

1. Finite State Machine With Output / Tranducer

a. Meanly Machine : Between states, there is a transition function.

b. Moore Machine : Output specified by state

2. Finite State Machine With No Output

\section{Tranducer}

A transducer is a recognizer that issues an output string during movement. output can be e. The finite transducer is a finite automata which can output a string of output symbols on each move. Moore machine, output is associated with state.

1. Mesin Moore, output is associated with the state.

2. Mesin Mealy, output is associated with the transition.

\section{Vending Machine}

A Vending machine can be interpreted as a tool or machine to sell goods automatically. What is meant by automatic here is, actually, this vending machine does not require an operator to sell goods. Consumers can buy goods with this vending machine according to the consumer's wishes, and the vending machine also actually provides change if we buy goods with more money [15].

\section{Mesin Moore}

Moore's machine is a tuple of 6, i.e

$\mathrm{M}=\left(\mathrm{Q}, \sum, \Delta, \delta, \lambda, \mathrm{q}_{0}\right)$ where :

$\mathbf{Q}=\mathbf{A}$ finite set of states

$\sum=$ A finite set of alphabetic symbols

$\Delta=$ Output symbol set (output alphabet)

$\delta=$ Mapping transition function $\mathrm{Q} \times \sum \mathrm{ke} \mathrm{Q}$.

$\lambda=$ Functions that map $\mathrm{Q}$ to $\Delta$, provides the output associated with each status.

$\mathrm{q}_{0}=$ initial status, member $\mathrm{Q}$.

Output $\mathrm{M}$ is a response to input $\mathrm{a}_{1} \mathrm{a}_{2} \ldots$ an, dimana $\mathrm{n} \geq 0$, is $\lambda\left(\mathrm{q}_{0}\right) \lambda\left(\mathrm{q}_{01}\right) \ldots \lambda\left(\mathrm{q}_{0 \mathrm{n}}\right)$ where $\mathrm{q}_{0}$, $\mathrm{q}_{1}, \ldots \mathrm{qn}$ It's a state line up. $\delta\left(\mathrm{q}_{\mathrm{i}^{-1},}, \mathrm{a}_{\mathrm{i}}\right)=\mathrm{q}_{\mathrm{i}}$ for $1 \leq \mathrm{i} \leq \mathrm{n}$. 
Moore engine delivers output $\lambda\left(\mathrm{q}_{0}\right)$ in response to feedback $\varepsilon$. DFA can be viewed as a special case of moore machines where alphabet output is $\{0,1\}$ and state $q$ is accepted if and only if $\lambda(q)=1$.

Example of a moore machine :

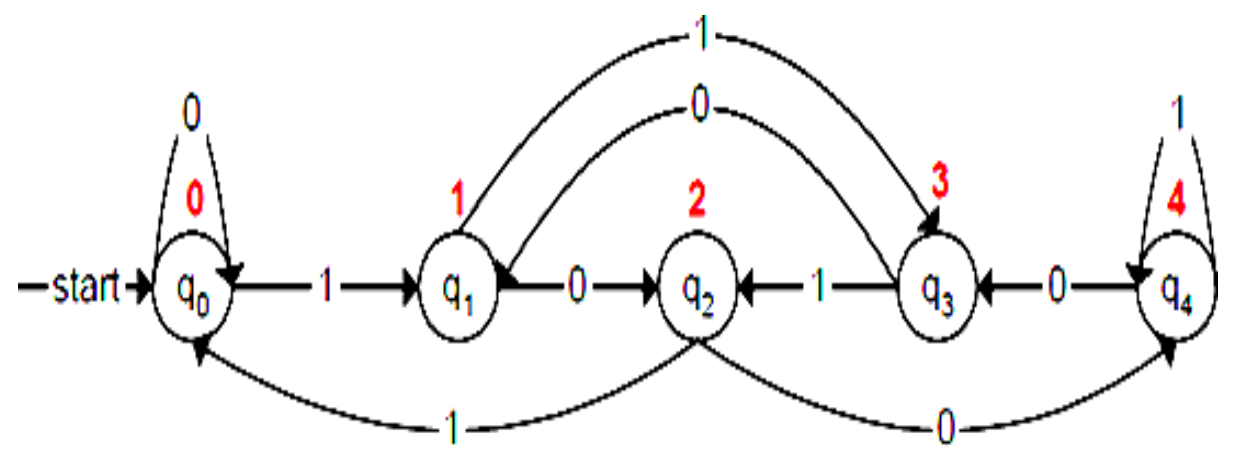

Gambar 1 : Moore Machine

\section{Mesin Mealy}

Mealy machine concept which is a development of finite state automata [16]. Mesin mealy is tuple 6 that is $\mathrm{M}=\left(\mathrm{Q}, \sum, \Delta, \delta, \lambda, \mathrm{q}_{0}\right)$ where:

$\mathbf{Q}=$ Status-finite set

$\sum=$ Infinite set of alphabet symbols

$\Delta=$ Set of output symbols (output alphabets)

$\delta=$ Transition function that maps $Q x \sum$ to $Q$.

$\lambda=$ Functions that map $\mathrm{Q} \times \sum$ to $\Delta, \lambda(\mathrm{q}, \mathrm{a})$ provides the output associated with the transition from q to the output sombol a.

$\mathrm{q}_{0}=$ initial status, member $\mathrm{Q}$.

Examples of Mealy Machines:

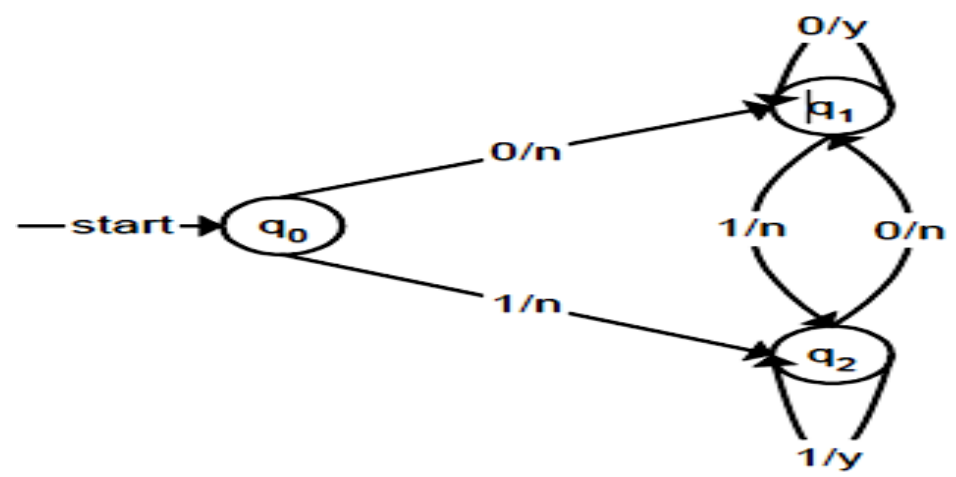

Gambar 2: Meanlu Machine

\section{RESULTS \& DISCUSSION}

\section{Simulation Implementation}

The first thing that must be done in making the simulation is to create a procedure to display the transition table, the program to display the transition table and the display after it is run. 


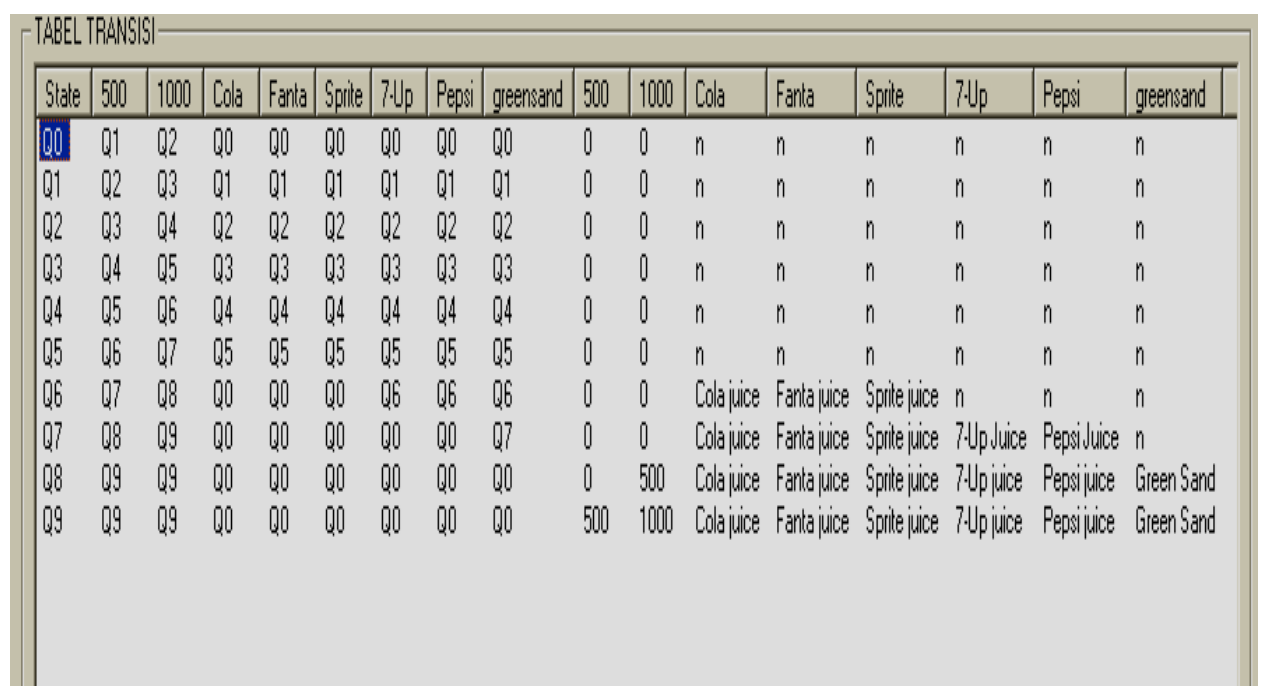

Figure 3: Running Program Transition View

The program to display the transition table above refers to the transition table that has been created in the design. The input program will accept the input, in this case, coins, and will add the previously entered coins to the coins entered. For example, enter the first coin at 1000 and the second coin at 500, then the result of the sum with the input program is 1500 . The input program and the input program display after running.

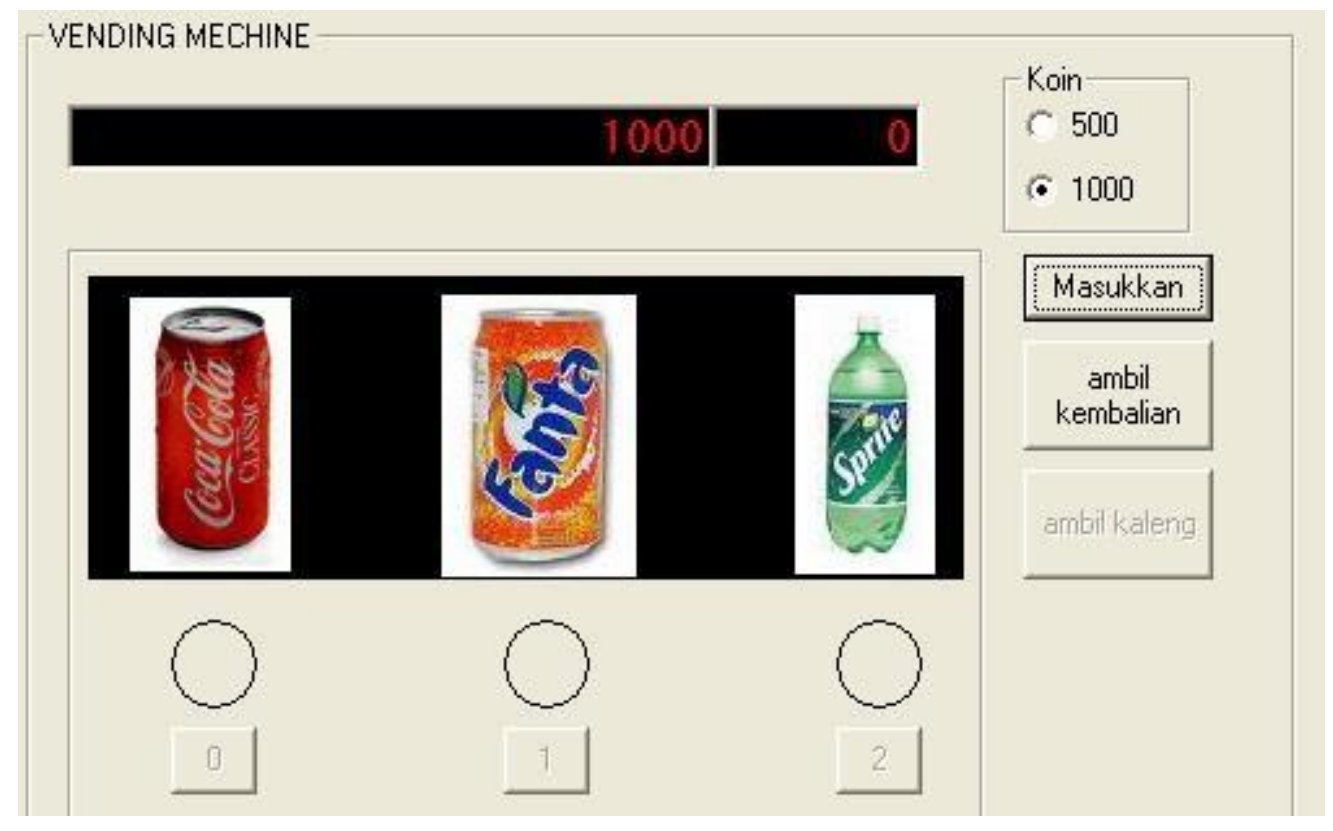

Figure 4: Coin Input Program 1000

\section{Vending Machine Implementation}

In making the application, some additional controls are needed which are not available in the intrinsic control. These additional controls are mscomctl.ocx(ListView). Display of the simulation form that has been created. 


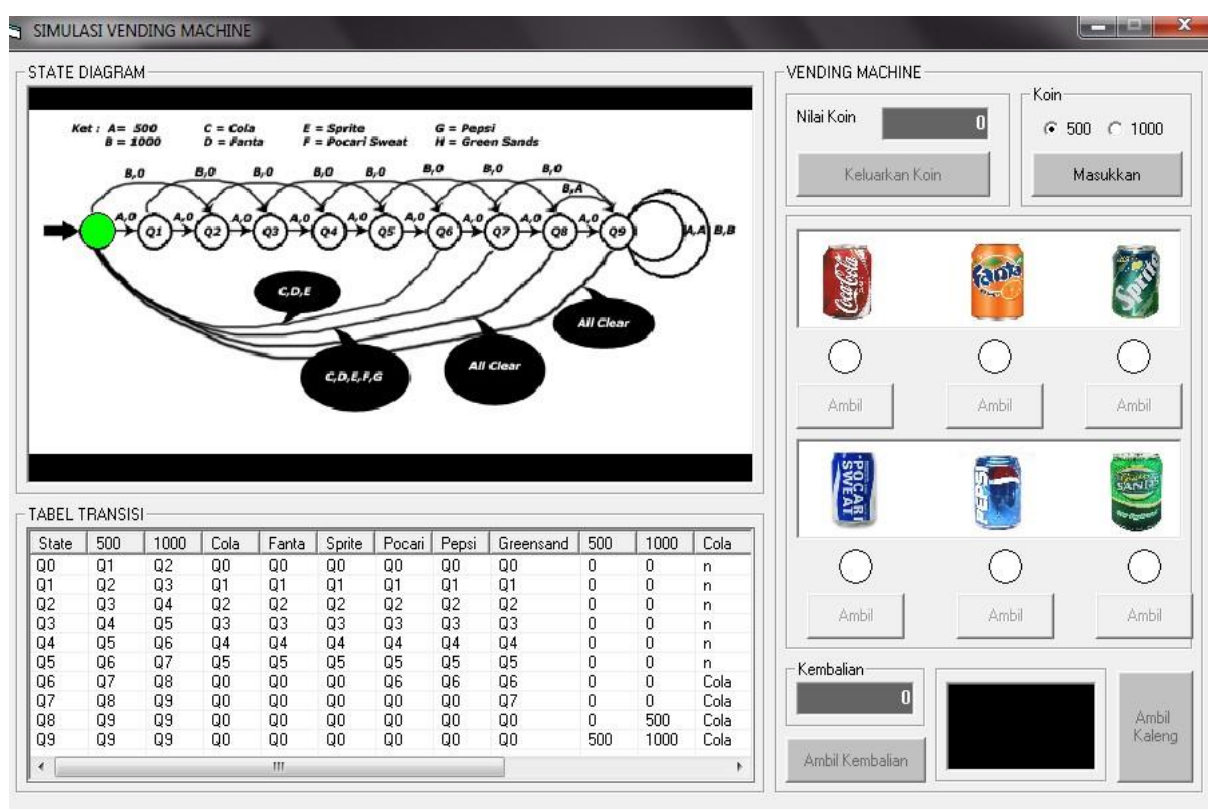

Figure 5: Simulation View.

\section{Vending Machine Simulation}

The main program view of this vending machine simulation. In this main program will be processed vending machine simulation.

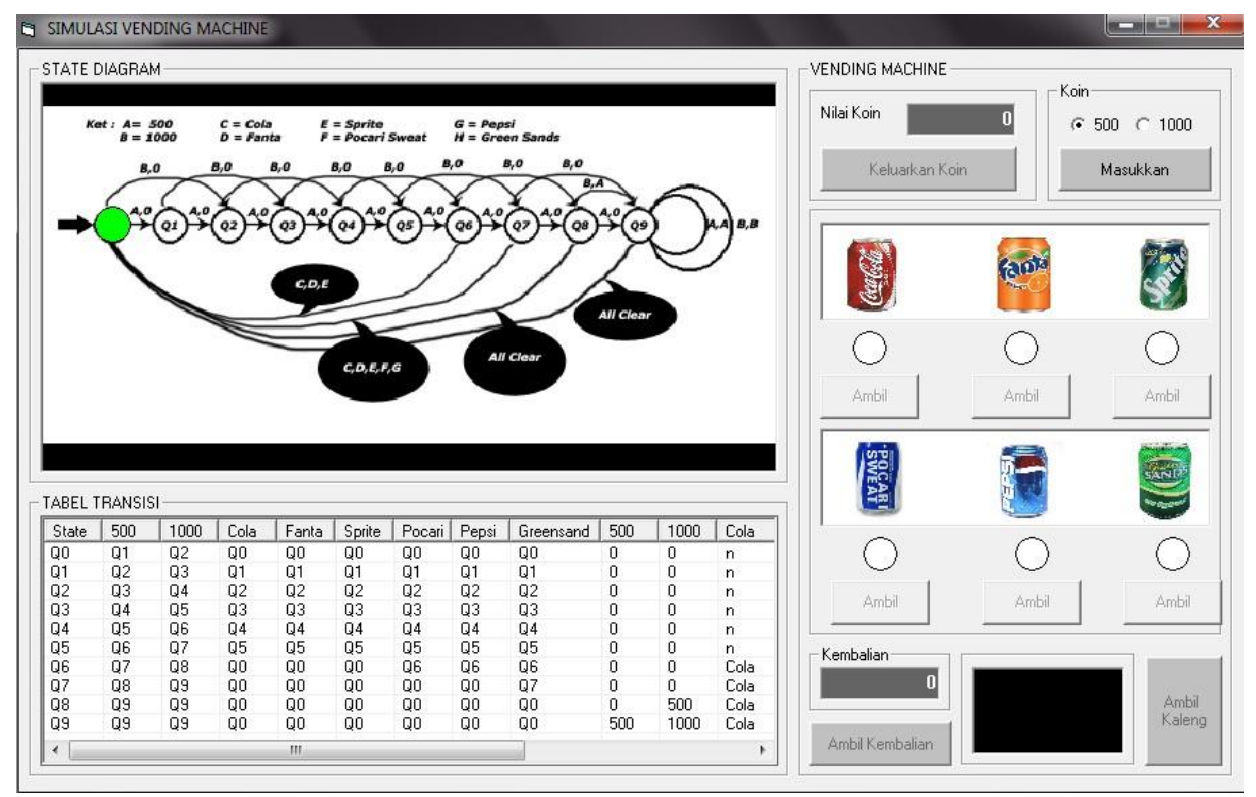

Figure 6: Vending Machine.

For the process of simulating vending machines, the input of coins is 500 and input again with the number of coins is 1000 . In the state diagram there will be a movement of the search for the value of the coin that is inputted. 


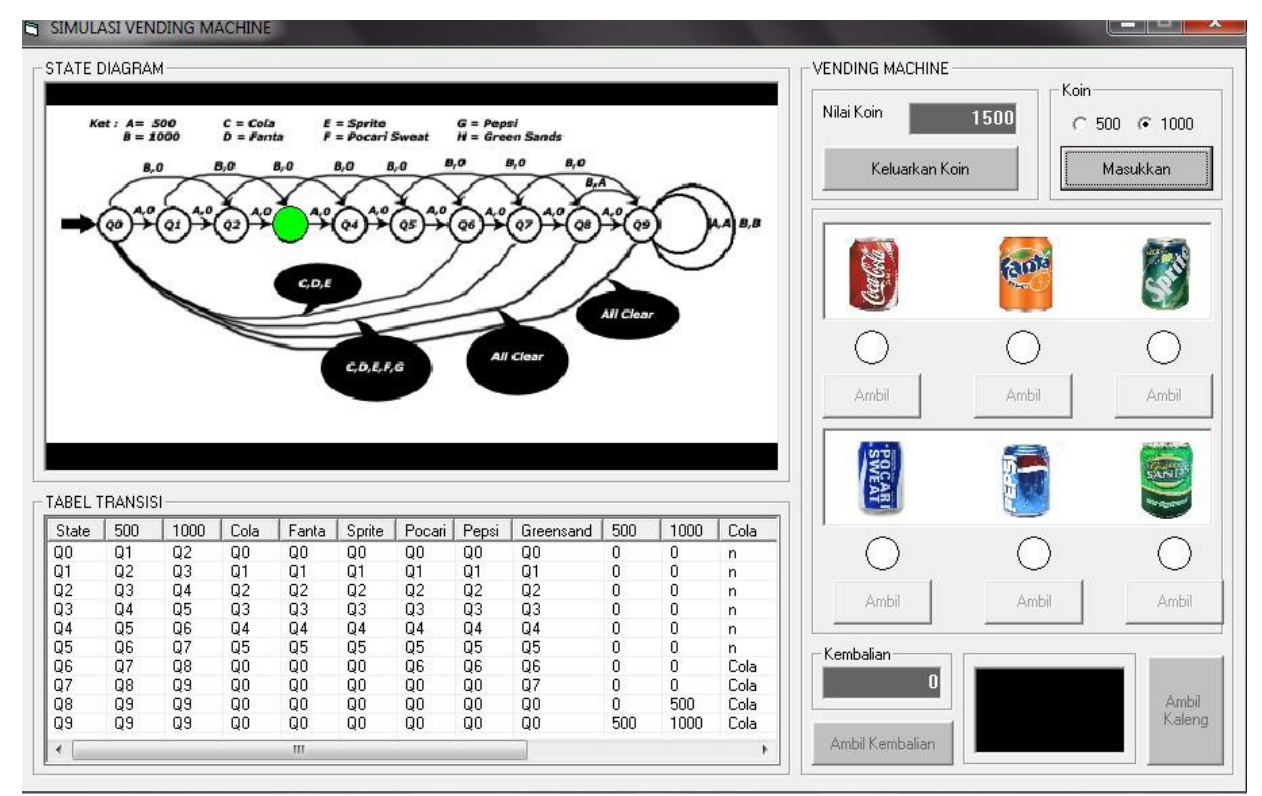

Figure 7: Coin Input Simulation

The entry of 1000 coins is made three times until the number of con entered is 3500. The simulation process on the status diagram will run as well as the transition table will perform a search.

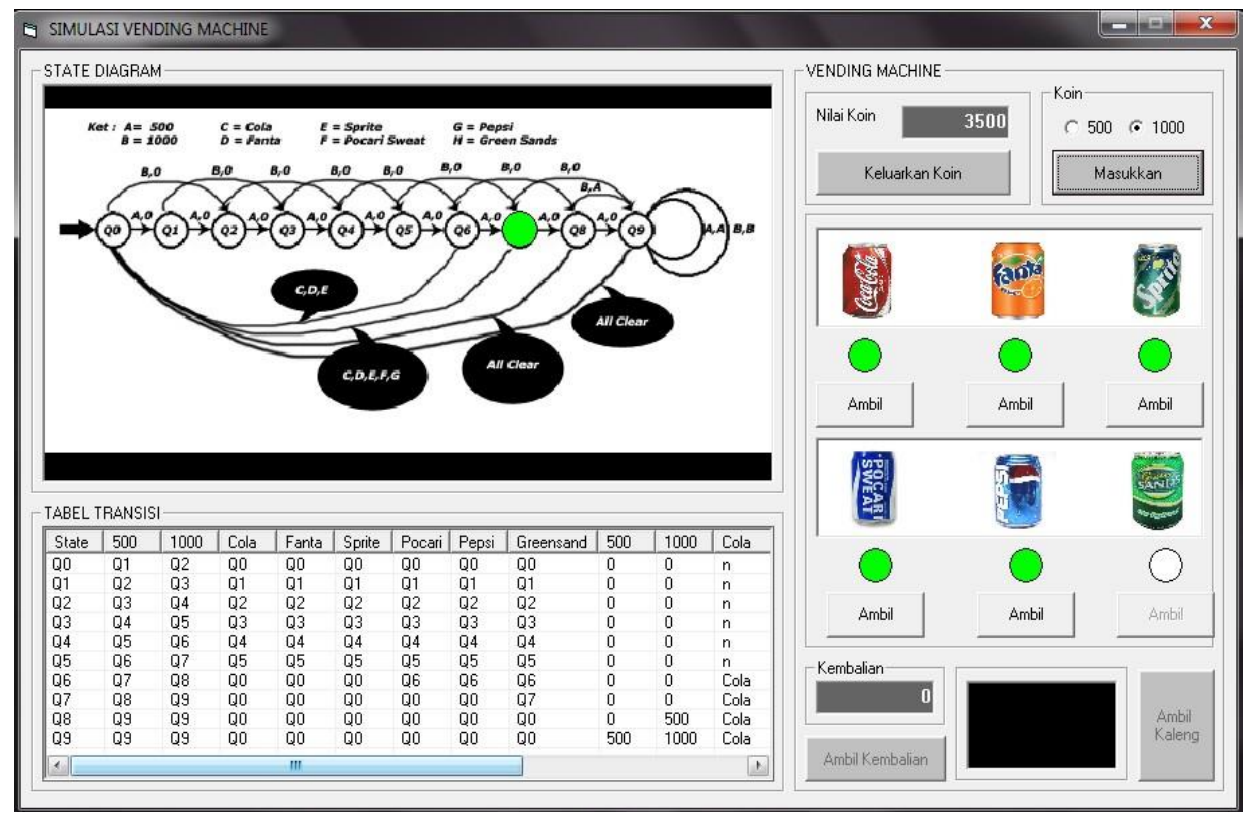

Figure 8: Veinding Machine Simulation

The input of 1000 coins to coins amounted to 4500. In this section is done the selection of the type of drink.if the money is inputted more then there is a return that is reduced the price of the drink. 


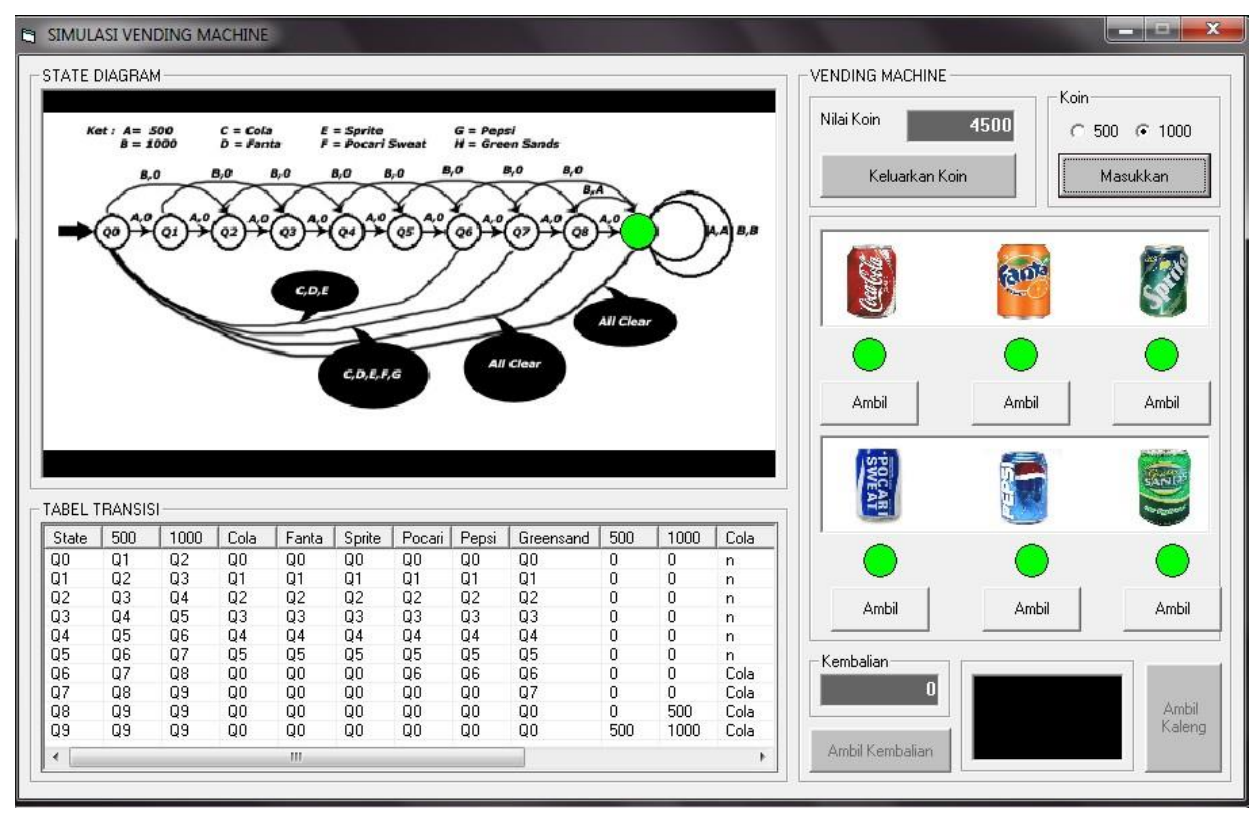

Figure 9: Selection of Beverages On Veinding Machine

Based on the results of the implementation of the study below is the data used to process requests to machines.

Table 1: Vending Machine Input Transition

\begin{tabular}{ccccccccc}
\hline State & 500 & 1000 & Cola & Sprite & Fanta & Pepsi & 7-up & Green sand \\
\hline Q0 & Q1 & Q2 & Q0 & Q0 & Q0 & Q0 & Q0 & Q0 \\
Q1 & Q2 & Q3 & Q1 & Q1 & Q1 & Q1 & Q1 & Q1 \\
Q2 & Q3 & Q4 & Q2 & Q2 & Q2 & Q2 & Q2 & Q2 \\
Q3 & Q4 & Q5 & Q3 & Q3 & Q3 & Q3 & Q3 & Q3 \\
Q4 & Q5 & Q6 & Q4 & Q4 & Q4 & Q4 & Q4 & Q4 \\
Q5 & Q6 & Q7 & Q5 & Q5 & Q5 & Q5 & Q5 & Q5 \\
Q6 & Q7 & Q8 & Q0 & Q0 & Q0 & Q6 & Q6 & Q6 \\
Q7 & Q8 & Q9 & Q0 & Q0 & Q0 & Q0 & Q7 & Q7 \\
Q8 & Q9 & Q9 & Q0 & Q0 & Q0 & Q0 & Q0 & Q8 \\
Q9 & Q9 & Q9 & Q0 & Q0 & Q0 & Q0 & Q0 & Q0 \\
\hline
\end{tabular}

Table 2: Vending Machine Output Transition

\begin{tabular}{ccccccccc}
\hline State & 500 & 1000 & cola & sprite & Fanta & pepsi & 7-up & Green sand \\
\hline Q0 & 0 & 0 & $\mathrm{~N}$ & $\mathrm{~N}$ & $\mathrm{~N}$ & $\mathrm{~N}$ & $\mathrm{~N}$ & $\mathrm{~N}$ \\
Q1 & 0 & 0 & $\mathrm{~N}$ & $\mathrm{~N}$ & $\mathrm{~N}$ & $\mathrm{~N}$ & $\mathrm{~N}$ & $\mathrm{~N}$ \\
Q2 & 0 & 0 & $\mathrm{~N}$ & $\mathrm{~N}$ & $\mathrm{~N}$ & $\mathrm{~N}$ & $\mathrm{~N}$ & $\mathrm{~N}$ \\
Q3 & 0 & 0 & $\mathrm{~N}$ & $\mathrm{~N}$ & $\mathrm{~N}$ & $\mathrm{~N}$ & $\mathrm{~N}$ & $\mathrm{~N}$ \\
Q4 & 0 & 0 & $\mathrm{~N}$ & $\mathrm{~N}$ & $\mathrm{~N}$ & $\mathrm{~N}$ & $\mathrm{~N}$ & $\mathrm{~N}$ \\
Q5 & 0 & 0 & $\mathrm{~N}$ & $\mathrm{~N}$ & $\mathrm{~N}$ & $\mathrm{~N}$ & $\mathrm{~N}$ & $\mathrm{~N}$ \\
Q6 & 0 & 0 & Cola & Sprite & Fanta & $\mathrm{N}$ & $\mathrm{N}$ & $\mathrm{N}$ \\
Q7 & 0 & 0 & Cola & Sprite & Fanta & Pepsi & $\mathrm{N}$ & $\mathrm{N}$ \\
Q8 & 0 & 500 & Cola & Sprite & Fanta & Pepsi & 7-Up & $\mathrm{N}$ \\
Q9 & 500 & 1000 & Cola & Sprite & Fanta & Pepsi & 7-Up & Green sand \\
\hline
\end{tabular}


In this study, the grammar used is as follows: $M=(S,(500,1000),(500,1000$, cola, sprite, fanta, pepsi, 7up, greensand), Q, G, Q0) with limitations:

\begin{tabular}{|c|c|c|c|}
\hline $\mathrm{S} \rightarrow 500 \mathrm{~A}$ & $S \rightarrow 1000 B$ & $\mathrm{~A} \rightarrow 500 \mathrm{~B}$ & $\mathrm{~A} \rightarrow 1000 \mathrm{C}$ \\
\hline $\mathrm{B} \rightarrow 500 \mathrm{C}$ & $\mathrm{B} \rightarrow 1000 \mathrm{C}$ & $\mathrm{C} \rightarrow 500 \mathrm{D}$ & $\mathrm{C} \rightarrow 1000 \mathrm{E}$ \\
\hline $\mathrm{D} \rightarrow 500 \mathrm{E}$ & $\mathrm{D} \rightarrow 1000 \mathrm{E}$ & $\mathrm{E} \rightarrow 500 \mathrm{~F}$ & $E \rightarrow 1000 G$ \\
\hline $\mathrm{F} \rightarrow 500 \mathrm{G}$ & $\mathrm{F} \rightarrow 1000 \mathrm{H}$ & $\mathrm{G} \rightarrow 500 \mathrm{H}$ & $\mathrm{G} \rightarrow 1000 \mathrm{I}$ \\
\hline $\mathrm{H} \rightarrow 500 \mathrm{I}$ & $\mathrm{H} \rightarrow 1000 \mathrm{I}$ & $\mathrm{I} \rightarrow 500 \mathrm{I}$ & $\mathrm{I} \rightarrow 1000 \mathrm{I}$ \\
\hline Cola S & $\mathrm{F} \rightarrow$ Sprite $\mathrm{S}$ & $\mathrm{F} \rightarrow$ Fanta $S$ & Cola S \\
\hline Sprite S & $\mathrm{G} \rightarrow$ Fanta $S$ & $G \rightarrow$ Pepsi $S$ & $\mathrm{H} \rightarrow$ Cola $\mathrm{S}$ \\
\hline Sprite S & $\mathrm{H} \rightarrow$ Fanta $\mathrm{S}$ & $\mathrm{H} \rightarrow$ Pepsi S & $7-\mathrm{Up} \mathrm{S}$ \\
\hline $\begin{array}{l}\text { Cola } S \\
-U p S\end{array}$ & $\begin{array}{l}\mathrm{I} \rightarrow \text { Sprite } \mathrm{S} \\
\mathrm{I} \rightarrow \text { Green Sand S }\end{array}$ & $I \rightarrow$ Fanta $S$ & $\mathrm{I} \rightarrow$ Pepsi $\mathrm{S}$ \\
\hline
\end{tabular}

Based on the results of research and analysis of making vending machine simulations and having arrived at the application implementation, the following conclusions can be drawn: A vending machine simulation application has been created that can explain how vending machines work. The vending machine simulation that is made can accept 500 and 1000 coins as input and produces output in the form of a description of the selected drink and the remaining coins that have been entered. The state must start from Q0 and the state in this study is limited to Q9.

\section{CONCLUSION}

Based on the results of research and analysis of making vending machine simulations and having arrived at the application implementation, the following conclusions can be drawn: A vending machine simulation application has been created that can explain how vending machines work. The vending machine simulation that is made can accept 500 and 1000 coins as input and produces output in the form of a description of the selected drink and the remaining coins that have been entered.

\section{REFERENCES}

[1] T. I. Saputra, F. Fauziah, and A. Gunaryati, "Simulasi Vending Machine Dengan Mengimplementasikan Finite State Automata," JOINTECS (Journal Inf. Technol. Comput. Sci., vol. 3, no. 3, 2018, doi: 10.31328/jointecs.v3i3.819.

[2] eko rosal Syawal, "Mesin Cnc," Politek. Bosowa, vol. 1, no. 123456, 2019.

[3] T. H. Wicaksono, F. D. Amrizal, and H. A. Mumtahana, "Pemodelan Vending Machine dengan Metode FSA ( Finite State Automata )," DoubleClick J. Comput. Inf. Technol., vol. 2, no. 2, 2019.

[4] D. Sujana, A. Hanipah, E. D. Agustina, S. S, and Y. Aulia, "Analisis Vending Machine Menggunakan Metode Finite State Automata (FSA) Di Gedung Lama Universitas Islam Syekh Yusuf Tangerang," UNISTEK, vol. 6, no. 1, 2019, doi: 10.33592/unistek.v6i1.169.

[5] M. F. Rahadian, A. Suyatno, and S. Maharani, "Penerapan Metode Finite State Machine Pada Game 'The Relationship,"' Inform. Mulawarman J. Ilm. Ilmu Komput., vol. 11, no. 1, 2016, doi: 10.30872/jim.v11i1.198.

[6] F. Alamsyah, W. Diwa, and A. Yunus, "IMPLEMENTASI ALGORITMA COLLISION DETECTION DAN FINITE STATE MACHINE UNTUK 
KARAKTER MUSUH PADA GAME BERTIPE METROIDVANIA," RAINSTEK J. Terap. Sains Teknol., vol. 1, no. 2, 2019, doi: 10.21067/jtst.v1i2.3062.

[7] D. M. Anugraha, I. Agustina, and F. Fauziah, "Game Edukasi Berbasis Kinect untuk Anak Berkebutuhan Khusus (Autis) dengan Metode Finite State Machine," JOINTECS (Journal Inf. Technol. Comput. Sci., vol. 3, no. 1, 2018, doi: 10.31328/jointecs.v3i1.501.

[8] F. K. Utama, "Shooter Game Underwater Mutation Menggunakan Metode Fsm ( Finite State Machine )," JATI (Jurnal Mhs. Tek. Inform., vol. 1, no. 1, 2017.

[9] F. Z. Arridho, "Game Edukasi Pengumpulan Sampah Organik Dan Anorganik Menggunakan Finite State Machine," JATI(Jurnal Mhs. Tek. Inform., vol. 1, no. 1, 2017.

[10] R. Juhadilah, "PENGARUH DAYA TARIK DAN KEPERCAYAAN TERHADAP KEPUTUSAN PEMBELIAN PRODUK MINUMAN PADA VENDING MACHINE DENGAN MINAT BELI SEBAGAI VARIABEL INTERVENING STUDI KASUS PADA PT PUTRI AUARIUS DI SIDOARJO," Manaj. Pemasar., 2019.

[11] N. Yuliani and D. Novita, "Kualitas Pelayanan 'Vending Machine' dengan Metode Importance and Performance Analysis pada PT KAI Commuterline Jabodetabek," J. Ekon. Manaj. dan Perbank., vol. 4, no. 1, 2018.

[12] P. Handoko, H. Hermawan, and S. Jaya, "Reverse Vending Machine Penukaran Limbah Botol Kemasan Plastik Dengan Tiket Sebagai Alat Tukar Mata Uang," Semin. Nas. Sains dan Teknol. 2018, 2018.

[13] Andrew Sebastian Lehman, Joseph Sanjaya, "Perancangan Mesin Penjual Makanan Ringan Otomatis," Sist. Komput. Univ. Kristen Maranatha Bandung Jl Suria Sumantri 65, Bandung 40164, 2017.

[14] Alfie Syahri, "DESAIN KONTROL VENDING MESIN BERBASIS FPGA DENGAN FINITE STATE MACHINE," J. Ilm. Inform. Komput., vol. 21, 2016.

[15] N. Afni and I. Akil, "Analisis Tingkat Kepuasan Pengguna Commuter Line Terhadap Commuter Vending Machine dengan Metode Technology Acceptance Model Pada," Simnasiptek 2017, no. 1980, 2017.

[16] A. Fauzan and S. Hartati, "Text to Speech untuk Bahasa Arab Menggunakan Perangkaian Diphone," JUITA J. Inform., vol. 6, no. 1, 2018, doi: 10.30595/juita.v6i1.1787. 